\title{
Correction to: In vivo digestibility of six selected fodder species by goats in northern Ghana
}

\author{
F. K. Avornyo ${ }^{1}$ - S. T. Partey ${ }^{2}$-R. B. Zougmore ${ }^{2}$-S. Asare ${ }^{3}$ - A. A. Agbolosu ${ }^{3}$ - N. M. Akufo ${ }^{3}$ - N. A. Sowah ${ }^{4} \cdot$ S. P. Konlan $^{1}$
}

Published online: 31 January 2020

(C) The Author(s) 2020

\section{Correction to: Tropical Animal Health and Production. https://doi.org/10.1007/s11250-019-01989-w}

The article "In vivo digestibility of six selected fodder species by goats in northern Ghana," written by F. K. Avornyo, S. T. Partey, R. B. Zougmore, S. Asare, A. A. Agbolosu, N. M. Akufo, N. A. Sowah, and S. P. Konlan, was originally published electronically on the publisher's internet portal (currently SpringerLink) on 13 July 2019 without open access.

With the author(s)' decision to opt for Open Choice the copyright of the article changed on January 2020 to (C) The Author(s) 2020 and the article is forthwith distributed under the terms of the Creative Commons Attribution 4.0 International License (http://creativecommons.org/licenses/ by/4.0/), which permits use, duplication, adaptation, distribution and reproduction in any medium or format, as long as you give appropriate credit to the original author(s) and the source, provide a link to the Creative Commons license and indicate if changes were made.

The original article has been corrected.

The online version of the original article can be found at https://doi.org/ 10.1007/s11250-019-01989-w

\footnotetext{
F. K. Avornyo

favornyo@yahoo.com

1 Council for Scientific and Industrial Research, Animal Research Institute, Nyankpala Station, Tamale, Ghana

2 International Crops Research Institute for the Semi-Arid Tropics, BP 320 Bamako, Mali

3 University for Development Studies, Nyankpala Campus, Tamale, Ghana

4 Department of Animal Science, University of Ghana, Legon, Accra, Ghana
} 